\title{
Increase of Serum GH Concentration following TRH Injection in Patients with Primary Hypothyroidism
}

\author{
Noboru HAMADA*, Koetsu UOI*, Yoshiki NISHIZAWA*, \\ TERUO OKAMOTO*, KOICHI HASEGAWA, \\ Hirotoshi MORII* AND MASAHISA WADA* \\ * Second Department of Internal Medicine, Osaka City University \\ Medical School, Abeno-ku, Osaka 545 and \\ **Shirokita Municipal Hospital, Asahi-ku, Osaka 535
}

\begin{abstract}
Synopsis
The effect of TRH administration on serum GH was studied in 6 normal subjects, 13 patients with primary hypothyroidism and 6 thyrotoxic subjects. Although no appreciable changes of serum GH were noted in the normal subjects, TRH administration provoked an increase of serum GH in 6 out of 13 patients with primary hypothyroidism. Serum GH levels in response to TRH administration were decreased in patients who were euthyroid following treatment with a preparation of desiccated thyroid. In patients with hyperthyroidism, no significant response of serum GH was observed at 30 or $60 \mathrm{~min}$ after TRH administration. Some of the patients with hyperthyroidism showed a slight increase in serum GH at $120 \mathrm{~min}$ after TRH injection. These results suggest that hypothalamo-pituitary function regulating $\mathrm{GH}$ secretion is altered in patients with primary hypothyroidism.
\end{abstract}

Synthetic thyrotropin releasing hormone (TRH) has been shown to be a potent secretagogue for thyrotropin (TSH) and prolactin in both man (Anderson et al., 1971 ; Jacobs et al., 1971) and other species (Convey, 1973). Although serum growth hormone $(\mathrm{GH})$ generally shows no appreciable rise following administration of TRH to normal humans (Anderson et al., 1971), such responses have been described in pathological human states (Irie and Tsushima, 1972; Hasegawa et al., 1975; Maeda et al., $1975 \mathrm{a}$ and $\mathrm{b}$ ), in vivo in bovines (Convey, 1973) and rats (Kato et al., 1975), and in vitro using various animal preparations (Carlson et al., 1974; Machlin and Jacobs, 1973).

The effect of TRH on the pituitary release of TSH and prolactin is magnified in the presence of reduced circulating thyroid hormone (Snyder et al., 1973), and

Received for publication June 9, 1975 .
Lawrence et al. (1973) reported that some of their patients with primary hypothyroidism showed unusually exaggerated $\mathrm{GH}$ response to arginine infusion. This communication reports an abnormal response of serum $\mathrm{GH}$ to TRH in patients with primary hypothyroidism.

\section{Patients and Methods}

Six normal subjects ( 5 males and 1 female), aged 33-54, were selected for the control study. Thirteen patients with untreated primary hypothyroidism and 6 thyrotoxic subjects were included in this study. The influence of treatment with desiccated thyroid was studied in 2 out of 13 patients with primary hypothyroidism. Some of the clinical information and pertinent laboratory data of these hypothyroid patients are shown in Table 1. For the hyperthyroid patients, the clinical diagnosis was confirmed by laboratory investigation, and all the patients of this group were studied before treatment.

After overnight fasting, all subjects were given intravenously $500 \mu \mathrm{g}$ of synthetic TRH dissolved in 
Table 1. Laboratory and clinical data in patients with primary hypothyroidism

\begin{tabular}{|c|c|c|c|c|c|c|c|c|c|c|c|}
\hline Patients & $\begin{array}{l}\text { Age } \\
\text { and } \\
\text { sex }\end{array}$ & $\begin{array}{c}\mathrm{T}_{3-} \\
\mathrm{RSU} \\
\%\end{array}$ & $\begin{array}{c}\mathrm{T}_{4} \\
\mu \mathrm{g} / \mathrm{d} l\end{array}$ & $\begin{array}{l}\mathrm{TSH} \\
\mu \mathrm{U} / \mathrm{m} l\end{array}$ & $\underset{\%}{\text { BMR }}$ & $\begin{array}{c}\text { Cholesterol } \\
\mathrm{mg} / \mathrm{d} l\end{array}$ & $\underset{\%}{\mathrm{RAI}}$ & $\begin{array}{l}\text { Size of } \\
\text { thyroid } \\
\text { gland } \\
\text { (grade)*** }\end{array}$ & $\begin{array}{l}\text { Thyroid } \\
\text { test }\end{array}$ & $\begin{array}{l}\text { Duration of } \\
\text { symptoms } \\
\mathrm{y}: \text { years } \\
\mathrm{m}: \text { months }\end{array}$ & $\begin{array}{l}\text { History of } \\
\text { replacement } \\
\text { therapy }\end{array}$ \\
\hline C. Y. & $46 \mathrm{~F}$ & 29.5 & 1.5 & 196 & -34.5 & 269 & 7.8 & 0 & $1: 100$ & $2 y$ & $(-)$ \\
\hline C. N. ${ }^{* *}$ & $48 \mathrm{~F}$ & 18.2 & 1.4 & 500 & -24.5 & 259 & - & 0 & $1: 100$ & $4 \mathrm{~m}$ & $(+)$ \\
\hline Y.K. & $45 \mathrm{~F}$ & 22.6 & 3.4 & 145 & - & 500 & - & I & $1: 400$ & $3 \mathrm{~m}$ & $(-)$ \\
\hline F. O. & $58 \mathrm{~F}$ & 19.5 & 3.7 & 82 & -22 & 219 & - & III & $1: 6553600$ & $5-6 y$ & $(-)$ \\
\hline A. Ko.* & $32 \mathrm{~F}$ & 23.5 & 1.4 & 125 & -27.5 & 235 & 5.2 & 0 & $1: 100$ & $2-3 y$ & $(-)$ \\
\hline K. T. ${ }^{* *}$ & $29 \mathrm{M}$ & 17.9 & 1.7 & 165 & -32.5 & 171 & 1.9 & 0 & $1: 100$ & $4-5 \mathrm{~m}$ & $(+)$ \\
\hline T. A. & $59 \mathrm{~F}$ & 19.3 & 2.5 & 351 & -21 & 260 & 32 & III & $1: 6553600$ & $3 m$ & $(-)$ \\
\hline A. Ka. & $31 \mathrm{~F}$ & 18.2 & 1.4 & 325 & -20 & 325 & 26 & III & $1: 6553600$ & $1 y$ & $(-)$ \\
\hline T. T.** & $39 \mathrm{M}$ & 19.0 & 1.9 & 300 & 一 & - & - & II & $1: 400$ & $1 y$ & $(+)$ \\
\hline F. K. & $58 \mathrm{~F}$ & 25.9 & 2.9 & 270 & - & 154 & - & 0 & $1: 100$ & $6 \mathrm{~m}$ & $(-)$ \\
\hline M.S. & $63 \mathrm{~F}$ & 22.8 & 3.7 & 172 & - & 171 & 22 & II & $1: 6553600$ & $1 y$ & $(-)$ \\
\hline U. W. & $68 \mathrm{M}$ & 21.4 & 2.1 & 150 & -11.5 & 211 & 22 & 0 & $1: 25600$ & $4 \mathrm{~m}$ & $(-)$ \\
\hline C. T. & $63 \mathrm{~F}$ & 21.0 & 3.6 & 72 & - & 171 & 31.6 & III & $1: 100$ & $1 \mathrm{~m}$ & $(-)$ \\
\hline
\end{tabular}

* Patient A.Ko. possessed a lingual thyroid.

** Patient C.N. had been treated until one month before the test, patient K.T. for 6 months at the age of 23, and patient T.T. for 6 months at the age of 37 .

*** Classification by Dieterle

Abbreviation: $\quad \mathbf{T}_{3}$-RSU ( ${ }^{131} \mathrm{I}-\mathrm{T}_{3}$ resin sponge uptake)

RAI ( $24 \mathrm{hr}$ radioactive iodine uptake)

Table 2. Serum TSH and GH levels following TRH administration in controls and patients with primary hypothyroidism and hyperthyroidism.

\begin{tabular}{l} 
r \\
\hline
\end{tabular}


$10 \mathrm{~m} l$ of sterile physiological saline. As a control study, $10 \mathrm{ml}$ of saline solution was injected intravenously in a patient with primary hypothyroidism. Blood samples were taken before, and 30,60 , and $120 \mathrm{~min}$ after the injection. Subjects were kept lying on bed and not allowed to sleep during the test.

Synthetic TRH was generously supplied by Tanabe Pharmaceutical Co., Japan. Serum TSH was determined by the method of double antibody radioimmunoassay (Odell et al. 1967), utilizing kits of Daiichi Radioisotope Labs., Ltd. and GH by the modified method of Schalch et al. (1964), utilizing kits of Dainabot RI Laboratory. The minimum detectable quantities of plasma serum GH and TSH were $0.2 \mathrm{ng} / \mathrm{m} l$ and $2.0 \mu \mathrm{U} / \mathrm{m} l$ respectively. The values of serum thyroxine and ${ }^{131} \mathrm{I}$-triiodothyronine resin sponge uptake were measured by using commercial kits (Tetrasorb and Triosorb Tests, Dainabot, Japan).

\section{Results}

Serum TSH values before and after TRH administration are shown in Table 2. While the maximum response was observed at 30 min in normal subjects, TSH levels were high in hypothyroid subjects and undetectable in thyrotoxic subjects before and after TRH injection.

The effects of TRH injection on serum $\mathrm{GH}$ in the three groups of subjects are shown in Table 2 and Fig. 1. The baseline level for the control was 0.4 to $1.2 \mathrm{ng} / \mathrm{m} l$ with a mean \pm SEM of $0.91 \pm 0.13 \mathrm{ng} / \mathrm{m} l$, and there was no significant change throughout the test period. The basal GH value in the patients with primary hypothyroidism was 0.5 to $4.7 \mathrm{ng} / \mathrm{m} l$ with a mean \pm SEM of $2.33 \pm 0.35 \mathrm{ng} / \mathrm{ml}$. As demonstrated in Fig. 1 , TRH administration provoked an increase of serum GH higher than $5 \mathrm{ng} / \mathrm{ml}$ in 6 out of 13 patients with primary hypothyroidism. Maximum response in serum GH after TRH injection was observed at $30 \mathrm{~min}$ in 4 patients (C. Y., F. O., A. Ko., A. K.) and at 60 min in 2 patients (M. S., C. T.). Serum GH levels in response to TRH administration were decreased in 2 patients, C. Y. and F. O., who were in the euthyroid state after treatment using a desiccated thyroid preparation. No significant change in GH level was observed in one patient (T.A.) who was administered $10 \mathrm{~m} l$ of saline instead of TRH solution: the basal level was $2.4 \mathrm{ng} / \mathrm{m} l$, and $2.4 \mathrm{ng} / \mathrm{m} l$ at $30 \mathrm{~min}, 1.85 \mathrm{ng} / \mathrm{ml}$ at $60 \mathrm{~min}$ and 1.75 $\mathrm{ng} / \mathrm{m} l$ at $120 \mathrm{~min}$ after saline administration, while a two-fold increase of serum GH was observed by TRH administration.

The basal GH level was 0.2 to $1.2 \mathrm{ng} / \mathrm{ml}$ with a mean $\pm S E M$ of $0.8 \pm 0.15 \mathrm{ng} / \mathrm{m} l$ and no significant response of serum GH was seen at 30 or $60 \mathrm{~min}$ after TRH administration
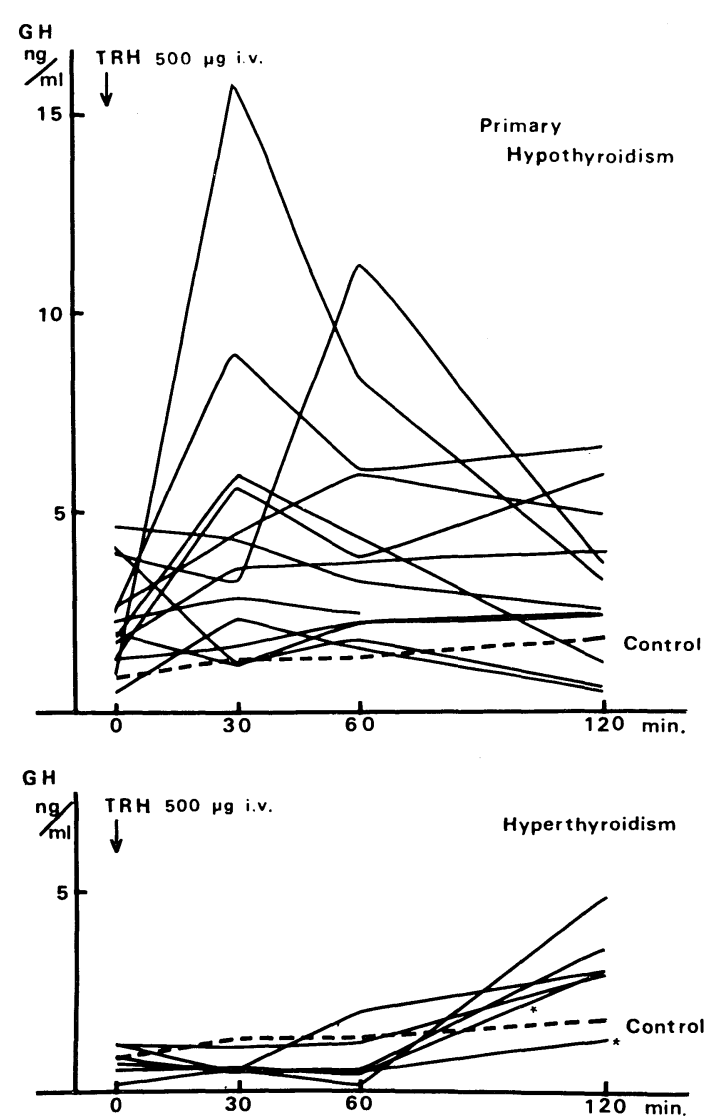

Fig. 1. Response of serum GH to TRH administration in 6 control subjects and patients with non-treated primary hypothyroidism and hyperthyroidism. *TRH test was performed after the initiation of the treatment with methimazole, but they were still in the state of hyperthyroidism at the time of the test. 
in patients with hyperthyroidism. Some of the patients with hyperthyroidism showed a slight increase in serum GH $120 \mathrm{~min}$ after TRH injection.

\section{Discussion}

Anderson et al. (1971), in the study on the effect of TRH in 80 normal subjects, observed a slight rise of mean $\mathrm{GH}$ values between 120 and $180 \mathrm{~min}$ after TRH administration, but the rise was not statistically significant. In the present study no appreciable changes of serum $\mathrm{GH}$ were noted in the normal subjects and patients with hyperthyroidism. It is very interesting that TRH provoked an increase of serum GH in 6 out of 13 patients with primary hypothyroidism and that the serum $\mathrm{GH}$ response to $\mathrm{TRH}$ decreased with the return to the euthyroid state. The six patients who showed a rise of serum GH after TRH injection were females and had not had replacement therapy. Their clinical symptoms of myxedema were severe and the duration of symptoms was longer than one year except for one case. However, other patients with severe symptoms of myxedema did not necessarily show a significant rise of serum $\mathrm{GH}$ after TRH administration and serum thyroxine, triiodothyronine resin sponge uptake, cholesterol, BMR and TSH levels did not seem to have a relationship with GH response after TRH administration.

Some explanation for the increased $\mathrm{GH}$ response to TRH in patients with primary hypothyroidism is needed, since a significant decrease in the $\mathrm{GH}$ response to insulininduced hypoglycemia in primary hypothyroidism and a satisfactory recovery in this response after treatment by desiccated thyroid have been reported (Iwatsubo et al., 1967). It has been stated that TRH is not entirely specific for TSH. It constantly releases prolactin with a time course similar to that of $\mathrm{TSH}$ release and in women occasionally releases LH (Hall et al., 1973). Recently a rise of serum GH following TRH injection in patients with acromegaly (Irie and Tsushima, 1972), chronic renal failure (Gonzalez-Barcoma et al., 1973 ; Hasegawa et al., 1975), anorexia nervosa (Maeda et al., 1975a), and depression (Maeda et al., $1975 b)$ has been reported and the specificity of the action of TRH on pituitary GH release is a matter of discussion.

Gagel et al. (1975) observed no significant difference in the urinary excretion of TRH between patients with hyperthyroidism and those with hypothyroidism, and proposed the absence of negative feedback mechanism as to TRH serection. However, there are dispute as to TRH levels in thyroid disorders. Although it has not been known whether TRH may influence the secretion of GH in hypothyroidism, Kato(1974)recently reported that GH response to TRH was increased by propylthiouracil administration and decreased by thyroxine administration in rats. A close relationship between $\mathrm{GH}$ and TSH secretion was also proposed. Guansing et al. (1975) observed TSH increase by insulin-induced hypoglycemia in pituitary disorders with decreased secretion of GH. It was also reported that $\mathrm{GH}$ may influence the $\mathrm{TRH}$ mediated secretion of TSH (Root et al., 1973). While somatostatin inhibited TSH secretion by TRH in normal people and in patients with primary hypothyroidism (Carr et al., 1975), the possibility of the participation of somatostatin in the regulation not only of GH but TSH serection in case of TRH administration should also be considered.

Histological descriptions of the pituitary in hypothyroid animals and humans have emphasized a paucity of eosinophils (Russfield, 1955) but other isolated reports have noticed either an increased number of eosinophils (Uyematsu, 1920) or an eosinophilic adenoma (Langeron et al., 1959) in patients dying of hypothyroidism. From this point of view, Lawrence et al. (1973) reported that some of his patients with 
primary hypothyroidism showed an unusually exaggerated $\mathrm{GH}$ response to arginine infusion. It is not considered that $\mathrm{GH}$ response to TRH is only due to such rare histological changes, since 6 of our 13 patients with hypothyroidism showed an increase in the GH response to TRH administration. This may be due to a mechanism involving hypothalamic hormonal induction of a new pituitary cell population possessing the capability of secreting several pituitary hormones.

The mechanism of $\mathrm{GH}$ release after TRH administration is not known at the present time. In a patient, A. Ko., serum GH increase after TRH administration was more pronounced than that after insulin-induced hypoglycemia. A similar response was recently observed in a patient with anorexia nervosa. The serum GH was markedly increased after TRH administration in this patient, but she showed a low GH response to arginine infusion and insulin-induced hypoglycemia. Therefore, the possibility must be considered that hypothalamic activity or the response of the pituitary cells is altered. Maeda et al. (1975 a and b) also proposed that altered metabolism of brain monoamines may change the response of $\mathrm{GH}$ to $\mathrm{TRH}$ in anorexia nervosa and depression. Since it was shown that the content of monoamines in hypothalamus changed in experimental hypothyroidism (Marthynenko et al., 1973), that GH secretion was shown to be influenced by brain monoamines (Boyd et al., 1970), and that TRH changed the metabolism of brain catecholamines (Keller et al., 1973; Plotnikoff et al., 1972), TRH may induce $\mathrm{GH}$ secretion by changing the metabolism of catecholamines in the brain in primary hypothyroidism.

\section{References}

Anderson, M. S., C. Y. Bowers, A. J. Kastin, D. S. Schalch, A. V. Schally, P. J. Snyder, R. Utiger, J. F. Wilber and A. J. Wise (1971). N. Engl. J. Med. 285, 1279.

Boyd, A. E., H. E. Levomitz and J. B. Pfeiffer (1970). Ibid. 283, 1425.

Carlson, H. E., I. K. Mariz and W. H. Daughaday (1974). Endocrinology 94, 1709.

Carr, D., A. Gomez-pan, D. R. Weightman, V. C. M. Roy, R. Hall, G. M. Besser, M. O. Thorner, A. S. McNeilly, A. V. Schally, A. J. Kastin and D. H. Coy (1975) Br. Med. J. 3, 67.

Convey, E. M., H. A. Tucker, V. G. Smith and J. Zolman (1973). Endocrinology 92, 471.

Gagel, R. F., I. M. D. Jackson, D. Duprez, P. D. Papapetrou and S. Reichlin (1975). Excerpta Med. Int. Congr. Ser. No. 361 abstracts of Seventh International Thyroid Conference, $\$ 22$.

Gonzalez-Barcena, D., A. J. Kastin, D. S. Schalch, M. Torres-Zamora, E. Perez-Pasten, A. Kato and A. V. Schally (1973). J. Clin. Endocrinol. Metab. $36,117$.

Guansing, A. R., Y. Leung, K. Ajlouni and T. C. Hagen (1975). Ibid. 40, 755.

Hall, R., D. C. Evere and W. M. G. Tunbridge Ninth Symposium on Advanced Medicine, Proceeding of a Conference held at the Royal College of Physicians of London, Geoffrey Walker, Pitman Medical, London, p. 15 (1973).

Hasegawa, K., Y. Matsushita, S. Otomo, N. Hamada, Y. Nishizawa, T. Okamoto, H. Morii and M. Wada (1975). Acta Endocrinol. 79, 635.

Irie, M. and T. Tsushima (1972). J. Clin. Endocrinol. Metab. 35, 97.

Iwatsubo, H., K. Omori, Y. Okada, M. Fukuchi, K. Miyai, H. Abe and Y. Kumahara (1967). Ibid. 27, 1751.

Jacobs, L. S., P. J. Snyder, R. D. Utiger, J. F. Wilber and W. H. Daughaday (1971). Ibid. 33, 996.

Kato, Y. (1974) presented at 22-nd meating of Western Branch of Japan Endocrinological Society.

Kato, Y., K. Chihara, K. Maeda, S. Ohgo, Y. Okanishi and H. Imura (1975). Endocrinology 96, 1114.

Keller, H. H., G. Bartholini and A. Pletscher (1973). Nature 248, 528.

Langeron, L., et al. (1959). Ann. Endocrinol. 20, 490.

Lawrence, A. M., J. F. Wilber and T. C. Hagen (1973). Arch. Intern. Med. 132, 327.

Machlin, L. J. and L. S. Jacobs (1973). Abstracts of the 55th Annual Meeting of the American Endocrine Society, p. 243.

Maeda, K., N. Yamaguchi, Y. Kato, K. Chihara, S. Ohgo, Y. Okanishi, Y. Yoshimoto, K. Moridera, 
S. Kuromaru and H. Imura (1975a). submitted to Acta Endocrinol.

Maeda, K., Y. Kato, S. Ohgo, K. Chihara, Y. Yoshimoto, N. Yamaguchi, S. Kuromaru and $\mathbf{H}$. Imura (1975b). J. Clin. Endocrinol. Metab. 40, 501. Marthynenko, F. P., O. N. Zryakov and N. P. Kornyushenko (1973). Ukr. Biokhim. Zh. 45, 624.

Odell, W. D., J. F. Wilber and W. E. Paul (1965). J. Clin. Endocrinol. Metab. 25, 1179.

Plotnikoff, N. P., A. J. Prange, Jr., G. R. Breese, M. S. Anderson and I. C. Wilson (1972). Science 178, 417.
Root, A. W., P. J. Snyder, I. Rezvani, A. M. Digeorge and R. D. Utiger (1973). J. Clin. Endocrinol. Metab. 36, 103.

Russfield, A. B. (1955). Ibid. 15, 1393.

Schalch, D. S. and M. L. Parker (1964). Nature 203, 1141.

Snyder, P. J., L. S. Jacobs, R. D. Utiger and W. H. Daughaday (1973). J. Clin. Invest. 52, 2324. Uyematsu, S. (1920). Arch. Neurol. Psychiat. 3, 252. 